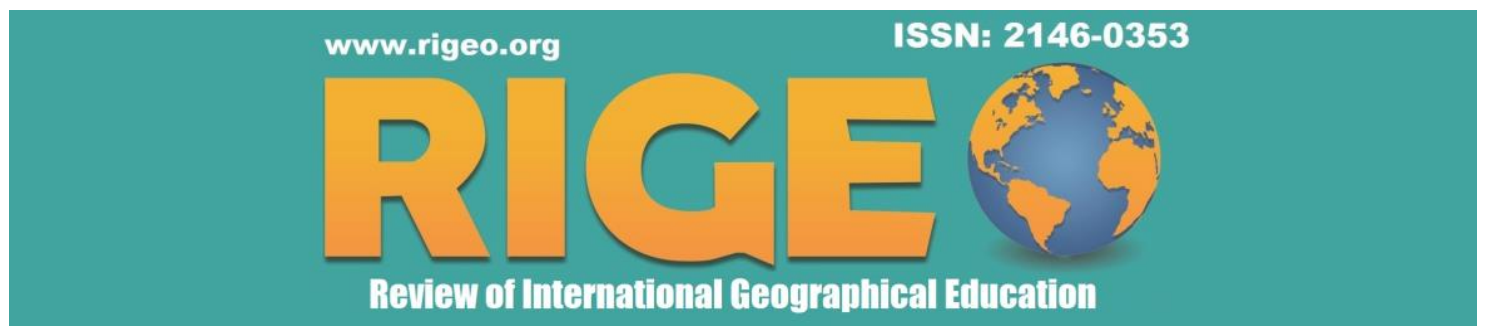

(C) RIGEO, Volume 10, Issue 1 (Special Issue), 2020

Research Article

Copyright @ RIGEO 2020

To cite this article: Kozaner Yenigül, C. (2020). Metaphoric Perceptions of Primary School Teacher Candidates on the Concept of Social Science and Its Teaching. Review of International Geographical Education (RIGEO), 10, (1), Special Issue, 120-139. Retrieved from http://www.rigeo.org/vol10no1/Number1Spring/RIGEO-V10-N1-6.pdf

DOI: 10.33403 rigeo.641587

Submitted: November 01, 2019

Revised: December 17, 2019

Accepted: February 02, 2020

\title{
Metaphoric Perceptions of Primary School Teacher Candidates on the Concept of Social Science and Its Teaching*
}

\author{
Çiğdem KOZANER YENİG̈̈ ${ }^{1}$ \\ European University of Lefke, Lefke, NORTHERN CYPRUS
}

\begin{abstract}
The aim of this study is to determine the perceptions of classroom teacher candidates towards the concept and teaching of social sciences through metaphors. In the 2018-2019 academic year, the Department of primary education of the Turkish Republic of Northern Cyprus, Lefke European University, Faculty of Education 1., 2., 3. and 4. there are 119 candidates of teachers who study in the classroom. Phenomenology design, one of the qualitative research methods, was used in the study. The data of the study was obtained through a semi-structured interview form. Content analysis technique was used in the analysis of the data. In this context, he produced 61 metaphors aimed at the concept of social sciences by participants. The metaphors produced were collected under 4 different conceptual categories. The metaphors produced by the class teacher candidates for the concept of social sciences were collected in 4 categories, "social - vital, interdisciplinary, cultural resource and primary education" respectively. The number of metaphors $(\mathrm{f}=27)$ in the "social-vital" category is greater when the metaphors developed by the teacher candidates according to the categories created for the concept of social sciences are taken into account. The most repeated in this category has been the metaphor of life $(f=20)$. The classroom teacher candidates produced 69 metaphors for teaching social sciences. The metaphors developed for the teaching of social sciences in line with the explanations made by the participants were grouped into 4 categories: "meeting social needs, interdisciplinary, knowledge transfer, cultural transfer," "When the metaphors developed by the teacher candidates according to the categories are taken into consideration, it is observed that the number of metaphors $(\mathrm{f}=31)$ in the "meeting the social needs" category for social sciences teaching is higher. The most repeated teaching of values in this category has been the metaphor $(\mathrm{f}=8)$.
\end{abstract}

Keywords

Primary School teacher candidates, Social Sciences Teaching, Metaphor, Qualitative Research

${ }^{*}$ A portion of this research was presented in 2. International Congress on Geographical Education (UCEK/ICGE-2019), 3-5 October 2019, Eskişehir-Turkey.

${ }^{1}$ Assist. Prof., European University of Lefke, Faculty of Education, Department of Turkish and Social Sciences Education, Lefke, Northern Cyprus, TR-10 via Mersin, Turkey, ckozaner [at] eul.edu.tr ORCID: 0000-0003-3849-3843 
Social sciences, which deals with the interaction of human beings with their social and physical environmental in time and continuity, has an important place in the primary education program. It aims at an understanding of citizenship with a focus on active participation in the democratic process as the main objective and makes an important contribution to the socialization of the child (Doganay, 2008). The topics of social sciences are directly related to the organization of society and the human being as a member of social groups. It differs from other works because of its content, rather than social aims. Due to the nature of their content, it offers the individual unique opportunities as a member of society (Dunn, 1916). Social sciences covers a wide range of content. This content draws students into a comprehensive process, with multiple dilemmas. Encourages students to think critically and make decisions about civics from a variety of perspectives (NCSS, 2016).

The social sciences course develops social activity for purposes such as raising individuals who are ready and willing to assume civic responsibilities and who can make informed decisions for the public as citizens of a democratic society (Passe, Good \& Libresco, 2014). The aim of this course is to provide students with social knowledge, skills, attitudes and values. In this context, it can be said that social sciences course is a designed for the purpose of socialization of the individual (Kaya \& Öner, 2017). To train individuals who will ensure the continuity of the expectations of the countries' own education systems. The way to achieve this goal will be through training effective citizens. In some countries, effective citizen training programs are provided with history, geography and citizenship knowledge in one-discipline understanding and in some countries with social sciences in interdisciplinary understanding (Tay, 2015).

Social sciences individuals, who loves his nation and homeland, knowing your rights and uses, in fulfilling their responsibilities, as citizens with national consciousness grow them; by understanding the culture and history that make up the basic elements and processes of Turkish national consciousness that allows the formation of protection and development of cultural heritage; the living environmental the general geographical features of the world with descriptions of the interaction between human and environmental by recognizing their skills and the development of place perception (MONE, 2018), such as in an interdisciplinary context serves many purposes. Raising children as responsible, highly aware and qualified individuals serves the present and future of societies.

In the creation of qualified societies, children are required to receive a qualified education from an early age (Gürdoğan Bayır, 2016). In this context, it can be said that while acquiring the knowledge and skills that children need will enable them to reach their individual development potential, it will also bring social benefits

Social sciences elementary school 4. grade and secondary school 5., 6. and 7. grade it is a course in the program. Given the content and purposes of social information, which is a primary education course of interest to the community, it also imposes responsibility on classroom teachers. In this context, it is important to determine the metaphors of the classroom teacher candidates who will teach the social sciences course in the future for the concept and teaching of social sciences. Because metaphors are important tools that 
reflect teacher candidates ' perspectives on the concept and teaching of social sciences and their past lives and present thoughts. Metaphor acts as a tool in describing a person's awareness and experiences.

Metaphor is a Greek word and consists of the words" meta: beyond "and" pherin: to carry "meaning" to tell one thing with another" (Parın, 2017). The nature of metaphor has long been studied in different respects. Traditionally metaphor is treated as part of figurative language, such as analogy, and is seen only as a feature of language (Ma \& Liu, 2008). The other functions of the metaphor, (Lakoff and Johnson, 1980) which were previously used with rhetorical and aesthetic concerns, were discovered over time and the introduction of a cognitive role to metaphor was realized through contemporary metaphor theory (Alpaslan \& Kutanis, 2007). Lakoff and Johnson (2003) have stated that metaphor is common in everyday life not only in language but also in thought and action; the terms we think and act with themselves are metaphorical by nature.

There are usually two explicit parts in metaphor: the being spoken about the subject, or the instrument, which is the metaphorical material relating to the subject. Some authors describe it as a target and source (Murphy, 1996). When perceiving concepts, it is often brought to mind what they have in common with another concept. When another characteristic of a concept is learned, often analogies are created in minds with the characteristics of other well-known situations. For this reason, metaphors appear in formal and informal learning as the expression of difficult concepts by analogy with known concepts. (Geçit \& Gencer, 2011).

Metaphors have been used to study and develop many areas of special education. (McCandless, 2012). When the literature is examined, there are many studies on different disciplines focused on metaphor in education (Saban, 2004; Gömleksiz et al.., 2012; Durmuş \& Baş, 2016; Beldağ \& Geçit, 2017; Değirmenci, 2019; Değirmenci \& Eskici, 2019). Exploring metaphors can enable us to study how people think and perceive. Metaphor acts as a tool to describe a person's awareness and experiences (Neuman \& Guterman, 2017; Massengil, Mahlios \& Barry, 2005). Metaphor is used when it is desired to explore and understand something esoteric, abstract, and speculative. In general, the more abstract and speculative the subject, the greater the variety of metaphors (Yob, 2003). While explaining abstract principles concrete examples are used in defining unknown and unseen reality through metaphors. It can help to make sense of what is happening in the creation, configuration and educational pursuits of images in these categories (Johnson, 1987; Çelikten, 2006).

Primary school teachers in Turkey, primary school 4. grade he is responsible for teaching social sciences in the classroom. Therefore, they should have sufficient knowledge about the concept and teaching of social sciences, and they should have sufficient knowledge about the disciplines that constitute the field of social sciences. From this perspective, the purpose of this study is to reveal the thoughts and perception that the classroom teachers who will give this course have about social sciences during their education. Through the "social sciences teaching" course in the primary education undergraduate program, it is possible to develop the past-based interest, perceptions and approaches of the teacher candidates to social sciences. In the scope of social sciences 
education, the aim of the research is to determine the meaning of the candidates of the classroom teachers to the concept and teaching of social sciences. For this purpose:

1. What are the metaphors of the primary school teacher candidates for the concept of social science and social sciences teaching?

2. What conceptual categories can the metaphors of primary school teacher candidates for the concept and teaching of social sciences be grouped under? Its questions have been answered.

\section{Methodology}

\section{Research Design}

This research is a descriptive study that examines the concept of social sciences and the metaphors developed by primary school teacher candidates for teaching social sciences. Qualitative research method was used in this study, which is a technique that allows regular analysis of the opinions drawing from individuals' experiences that have been or planned to be realized. Thus, phenomenology design, one of the qualitative research methods, was used in the study. Phenomenology design focuses on concepts that we are aware of yet lack a deep and comprehensive understanding of (Yıldırım \& Şimşek, 2008).

\section{Working Group}

In the 2018-2019 academic year, the study group was composed of the candidates of teachers studying in the Department of primary school teaching at Lefke European University, Turkish Republic of Northern Cyprus. The working group provides a method of sampling for the typical case sampling (Büyüköztürk et al., 2008) designated by. Data for the workgroup is given in Table 1.

Table 1

Distribution of classroom teacher candidates by grade level

\begin{tabular}{lcc}
\hline Grade & $\begin{array}{c}\text { Frekans } \\
(\mathbf{f})\end{array}$ & $\begin{array}{c}\text { Percent } \\
(\boldsymbol{\%})\end{array}$ \\
\hline 1. & 20 & 16.80 \\
\hline 2. & 39 & 32.77 \\
\hline 3. & 33 & 27.73 \\
\hline 4. & 27 & 22.69 \\
\hline Total & 119 & 100 \\
\hline
\end{tabular}

\section{Data Collection}

The research first examined the relevant literature while developing a data collection tool (Jensen, 2006; Gültekin, 2013; Kaya, 2014; Koçoğlu, 2014; Çelikkaya \& Yakar, 2015; Beldağ \& Geçit, 2016; Durmuş \& Baş, 2016; Değirmenci, 2019). In order to determine the perceptions of the primary school teacher candidates regarding the concept of social sciences and social sciences teaching, "social sciences....... like. Because ........." and teaching social sciences........ like. Because.......... a semi-structured interview form with statements is used. In the form, the personal information section, where teacher candidates can express their grade level, has also been used as a data collection tool. 
Participants were asked to write the metaphor they had regarding the concept and teaching of social sciences together with their reasons. They are given approximately one hour (50 min) to complete the form. Participants submitted the form within the first 30 minutes.

\section{Analysis of Data}

As part of the study, the general evaluation of the contents of social sciences textbooks referred to the textbooks given in Table 1, as well as various publications examining social sciences education curricula and textbooks of 1968, 1998, 2005 and 2018 in terms of content (Saban, 2009; Koçoğlu, 2014; Değirmenci, 2019). Content analysis technique was utilized in the analysis of the data obtained from the study. Content analysis, which is a widely used qualitative research method, is one of the research methods in which text data is analyzed based on the content or contextual meaning of the text. The process of content analysis involves bringing together similar data on the basis of certain concepts and themes and interpreting them in a way that is comprehensible for the reader (Y1ldirım and Şimşek, 2008). (Firstly, after reading all the papers, the metaphors of the candidates for the social sciences concept and social sciences teaching were listed and the metaphors developed by the participants were coded (e.g. Dream, Light, book, glasses, etc.). Metaphors were examined and the subject and reason of the metaphor were examined and the relationship was made meaningful. At this stage, some forms were not evaluated on the grounds that the participants did not offer any justification for a metaphor or leave null.

Of the 119 forms were excluded 7 from evaluation because they were not filled out for the purpose and 112 teacher candidates' forms were taken for evaluation. The resulting metaphors have been classified by considering the underlying thoughts and issues. In the category development phase, the metaphors classified are divided into categories according to their common characteristics for the concept and teaching of social sciences. Because the same metaphor reflects a different thought or subject, frequencies have also been included in multiple categories. The metaphors of the teacher candidates are tabulated according to their subcategories and the frequency (f) of each metaphor is given.

\section{Reliability and Validity}

After the data obtained in the study were encoded and categories were developed, a checklist of metaphors and justifications developed by the teacher candidates was created. The checklist includes repeated and only once expressed metaphors and sample sentences of participants. The checklist was sent to two experts in the field and revised with their opinions. The reliability of the study was calculated using the formula" reliability= ((Consensus): (Consensus+difference of opinion)) x 100 " (Miles \& Hubermann, 1994). Accordingly, the reliability of the study was calculated as 0.95 in the reliability analysis of the categories created for the concept of social sciences and 0.94 in the reliability analysis of the categories created for the teaching of Social Sciences.

The process is formulated as:

[Reliability $=((61):(61+3)) \times 100=>$ reliability $=95 \%$ ]

$[$ Reliability $=((65):(65+4)) \times 100=>$ reliability $=94 \%$ ] 


\section{Findings}

In this part of the research, the concept of social sciences and the metaphors developed by the participants for teaching social sciences are included in the categories developed based on these metaphors. Coding was used when presenting teacher candidates' opinions. The first letter is the participle, the second number is the ordinal number in the metaphor list, and the third number is the class level (for example, K.13.1.).

Table 2

Metaphors Produced by Primary School Teacher Candidates for the Concept of Social Sciences

\begin{tabular}{|c|c|c|c|c|c|}
\hline Range & Metaphors & $\begin{array}{l}\text { Frequency } \\
\text { (f) }\end{array}$ & Range & Metaphors & $\begin{array}{l}\text { Frequency } \\
\text { (f) }\end{array}$ \\
\hline 1. & Living & 20 & 32. & Female & 1 \\
\hline 2. & History & 5 & 33. & Geography & 1 \\
\hline 3. & Daily Life & 5 & 34. & $\begin{array}{l}\text { Preparing for } \\
\text { life }\end{array}$ & 1 \\
\hline 4 & Life & 5 & 35. & Salad & 1 \\
\hline 5. & Life itself & 4 & 36. & Country & 1 \\
\hline 6. & Tree branches & 3 & 37. & Sky & 1 \\
\hline 7. & Life itself & 3 & 38. & $\begin{array}{l}\text { Totality of } \\
\text { information }\end{array}$ & 1 \\
\hline 8. & History-Geography & 2 & 39. & Civilization & 1 \\
\hline 9. & Environmental & 2 & 40. & Postcard & 1 \\
\hline 10. & Map & 2 & 41. & Mixer & 1 \\
\hline 11. & Book & 2 & 42. & Dream & 1 \\
\hline 12. & Value & 2 & 43. & Sun & 1 \\
\hline 13. & Tree & 2 & 44. & Light & 1 \\
\hline 14. & Bag & 2 & 45. & Emergency & 1 \\
\hline 15. & World & 2 & 46. & Eat & 1 \\
\hline 16 & Library & 2 & 47. & Glasses & 1 \\
\hline 17. & Society & 2 & 48. & Love & 1 \\
\hline 18. & Water & 2 & 49. & Brain & 1 \\
\hline 19. & Socialization & 2 & 50. & Moon & 1 \\
\hline 20. & Sound & 1 & 51. & Door & 1 \\
\hline 21. & Family & 1 & 52. & Universe & 1 \\
\hline 22. & Encyclopedia & 1 & 53. & Spring & 1 \\
\hline 23. & Our life story & 1 & 54. & Dicipline & 1 \\
\hline 24. & Sea & 1 & 55. & Sycamore & 1 \\
\hline 25. & Sensitive human & 1 & 56. & Living & 1 \\
\hline 26. & Power Source & 1 & 57. & $\begin{array}{l}\text { Intertwined } \\
\text { with nature }\end{array}$ & 1 \\
\hline 27. & A developing city & 1 & 58. & Seed & 1 \\
\hline 28. & Culture & 1 & 59 & Breath & 1 \\
\hline
\end{tabular}


KOZANER YENIGÜL, Çiğdem (2020)/ Metaphoric Perceptions of Primary School Teacher Candidates on ....

\begin{tabular}{llllll}
\hline 29. & Mountain & 1 & 60 & Sentence & 1 \\
\hline 30. & Market place & 1 & 61 & Flower & 1 \\
\hline 31. & Hour & 1 & & & \\
\hline
\end{tabular}

\section{Metaphors for the Concept of Social Sciences}

According to the findings of the study, participants produced a total of 61 metaphors for the concept of social sciences. (sound, family, encyclopedia, our life story, the sea, sensitive human, power source, a developing city, culture, mountain, market place, hour, female, geography, preparation for life, salad, country, sky, the totality of the information, civilization, postcards, mixer, dream, sun, light, emergency, food, glasses, love, brain, moon, the doors, the universe, spring, discipline, live, intertwined with nature, seed, breathing, sentence, flower) metaphors produced by only one participant. Other metaphors " $(\mathrm{f}=20)$ Living, $(\mathrm{f}=5)$ History, $(\mathrm{f}=5)$ Life, $(\mathrm{f}=5)$ Daily life,$(\mathrm{f}=4)$ life itself, $(\mathrm{f}=3)$ tree branches, $(\mathrm{f}=2)$ history-geography, $(\mathrm{f}=2)$ environmental, $(\mathrm{f}=2)$ map $(\mathrm{f}=2)$ books, $(\mathrm{f}=2)$ values, $(\mathrm{f}=2)$ tree, $(\mathrm{f}=2)$ bags, $(\mathrm{f}=2)$ world, $(\mathrm{f}=2)$ library, $(\mathrm{f}=2)$ society, $(\mathrm{f}=2)$ water, $(\mathrm{f}=2)$ socialization" is shaped like.

\section{Category Distribution of Metaphors for the Concept of Social Sciences}

The metaphors produced by the class teacher candidates for the concept of social sciences were grouped in 4 categories: "Primary Education, interdisciplinary, social vital, cultural resource.

Table 3

Metaphors and categories for the concept of Social Sciences

\begin{tabular}{|c|c|c|c|c|}
\hline Range & Categories & Metaphor & $\begin{array}{l}\text { Metaphor } \\
\text { (f) }\end{array}$ & $\begin{array}{l}\text { Participant } \\
\text { (f) }\end{array}$ \\
\hline 1 & 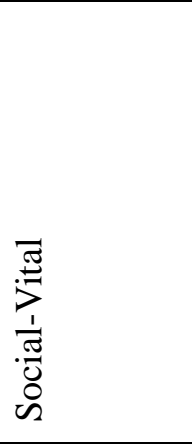 & $\begin{array}{l}\text { Living (20), Daily Life (5),Life (5) Life, } \\
\text { (4), Life Itself (3), Environmental (2), } \\
\text { Socialization (2), Water (2), Society (2), } \\
\text { Tree (2), The Sensitive human (1), } \\
\text { Power Source (1), Market Place (1), } \\
\text { Female (1) Sky (1) Sun (1), Light (1), } \\
\text { Glasses (1), Discipline (1)Sycamore (1), } \\
\text { Vivid (1), Intertwined with nature (1), } \\
\text { breathing (1), Flower (1) Sound (1) } \\
\text { Dream (1), map (1) }\end{array}$ & 27 & 64 \\
\hline 2 & 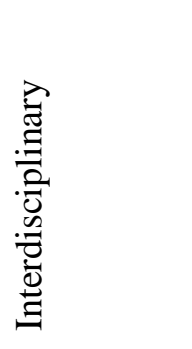 & $\begin{array}{l}\text { History (4), Tree Branches (3), Bag (2), } \\
\text { History-Geography (2), World (2), } \\
\text { Developing of City (1), Mountain (1), } \\
\text { Salad (1), Mixer (1), Love (1), } \\
\text { Country( 1), Society (1), Cabinet (1), } \\
\text { Sea (1), Universe (1), Totality of the } \\
\text { Information (1), Food (1), Door (1), } \\
\text { Sentence (1) }\end{array}$ & 19 & 28 \\
\hline
\end{tabular}




\begin{tabular}{lllll}
\hline 3 & & Value (2), Book (2), Moon (1), & 11 & 13 \\
& & Culture(1), Our Life Story(1), Postcard & & \\
& & (1), Map (1), Geography (1), & \\
& & Civilization(1), Encyclopedia (1), & & \\
\hline 4 & & History(1) & & \\
& & Family (1), Hour (1), Preparation for & 7 & \\
& & Life (1), Emergency (1), Brain (1), & & \\
& & & & \\
& & & & \\
\hline & & & 64 & 112 \\
\hline
\end{tabular}

\section{Social-Vital Category}

Teacher candidates have produced a total of 27 metaphors in the social-vital dimension of the concept of social sciences. According to the type of metaphors used , $(\mathrm{f}=20)$ living, $(\mathrm{f}=5)$ daily life, ( $\mathrm{f}=5)$ life, ( $\mathrm{f}=4)$ life, $(\mathrm{f}=3)$ life Itself, $(\mathrm{f}=2)$ environmental, $(\mathrm{f}=2)$ socialization, $(\mathrm{f}=2)$ water, $(\mathrm{f}=2)$ society,$(\mathrm{f}=2)$ tree,$(\mathrm{f}=1)$ sensible human, $(\mathrm{f}=1)$ power source, $(\mathrm{f}=1)$ to market place, $(\mathrm{f}=1)$ of female, $(\mathrm{f}=1)$ sky, $(\mathrm{f}=1)$ sun, $(\mathrm{f}=1)$ light, $(\mathrm{f}=1)$ glasses , $(\mathrm{f}=1)$ discipline , $(\mathrm{f}=1)$ sycamore, $(\mathrm{f}=1)$ vivid, $(\mathrm{f}=1)$ intertwined with nature, $(\mathrm{f}=1)$ breathing, $(\mathrm{f}=1)$ flower, $(\mathrm{f}=1)$ sound, $(\mathrm{f}=1)$ dream, $(\mathrm{f}=1)$ is shaped like the map of. As shown in Table 2, most metaphors are derived from the social-vital category. The most frequent expression of the "life" metaphor is included in this category. From the differences in analogy, the metaphor" society " is coded in the interdisciplinary and social-life category, while the metaphor of the map is coded in the social - vital and cultural resource category. When the analogy reasons of the teacher candidates are examined, it is seen that they address the importance of social information in the social dimension.

Examples of metaphors for this category are given below.

K32. 2. Social sciences is like life. Because it comes from the inside of your life.

K.86.3. Social sciences is like life. Because it deals with the issues of social life.

K.36.2. Social sciences is like life itself. Because it's always in our lives.

K.56.3. Social sciences is like a dream. Because if you don't tell me about your dream when you wake up, you forget it, you have to repeat it.

K.5.1. Social sciences is like a map. Because it leads.

K.7.1. Social sciences are like the environment. Because we get a lot of information from our environment.

K.107.4. Social sciences is like life itself. Because it is an area of Human Foundation.

K.13.1. Social sciences are like sensitive human. Because then it helps to keep it from being forced.

K34. 2. Social sciences is like life. Because it comes from the inside of your life.

K.30.2. Social sciences is like life itself. Because we get some experience, life skills and social skills.

\section{Interdisciplinary Category}

Teacher candidates have produced a total of 19 metaphors related to the interdisciplinary dimension of the concept of social sciences. When the grounds of the metaphors produced by the candidates of teachers are examined, it is stated that social 
information consists of many human disciplines and fields of study. According to the type of metaphors used $(\mathrm{f}=4)$ history, $(\mathrm{f}=3)$ the branches of the tree, $(\mathrm{f}=2)$ bag, $(\mathrm{f}=2)$ historygeography, $(\mathrm{f}=2)$ world, $(\mathrm{f}=1)$ the developing of city, $(\mathrm{f}=1)$ mountain, $(\mathrm{f}=1)$ salad, $(\mathrm{f}=1)$ mixer, $(\mathrm{f}=1)$ love, $(\mathrm{f}=1)$ country, $(\mathrm{f}=1)$ society, $(\mathrm{f}=1)$ cabinet, $(\mathrm{f}=1)$ sea, $(\mathrm{f}=1)$ Universe, $(\mathrm{f}=1)$ totality of the information, $(\mathrm{f}=1)$ food, $(\mathrm{f}=1)$ door and $(\mathrm{f}=1)$ is in the form of the sentence. Examples of metaphors for this category are given below.

K.44.2. Social sciences is like history. Because it is based on history, which then brings with it other sciences.

K28. 2. Social sciences are like branches of a tree. Because it has many branches.

K64. 3. Social sciences are like food. Because it's unique, but it's rich in content.

K11. 1. Social sciences are like the sea. Because the sea is deep and contains many creatures. K27. 2. Social sciences are like history and geography. Because it takes its subjects from these areas as well.

K63. 3. Social sciences are like a bag. Because we can find everything we need in it.

K16. 2. Social sciences is like the developing city. Because his subjects are always renewed and very broad.

K18. 2. Social sciences is a mountain. Because he's accumulated a lot of information in a row.

K42. 3. Social sciences is like a salad. Because there's a lot of stuff in there.

K55. 3. Social sciences is like a mixer. Because it mixes and connects a lot of areas.

K67. 3. Social sciences are like love. Because, it has a large scope at large.

\section{Cultural Resource Category}

Given the explanations related to the metaphors developed in the Cultural Resource category, it was determined that the candidates of primary education emphasized the role of social sciences in the transfer of cultural elements and characteristics. It appears that 11 different metaphors were developed by 12 teacher candidates. Teachers "cultural resource" category $(\mathrm{f}=2)$ value, $(\mathrm{f}=1)$ the book, $(\mathrm{f}=1)$ moon, $(\mathrm{f}=1)$ culture, $(\mathrm{f}=1)$ our life story, $(\mathrm{f}=1)$ postcard, $(\mathrm{f}=1)$ map, $(\mathrm{f}=1)$ geography, $(\mathrm{f}=1)$ civilization, $(\mathrm{f}=1)$ such as the encyclopedia of metaphors have produced. The" history "metaphor is also included in the" interdisciplinary " category due to differences in analogy.

Examples of metaphors for this category are given below.

K.76.3. Social sciences are like a value. Because our values reflect our culture that makes people human.

K.70.3. Social sciences is like the moon. Because the sun reflects the light of the moon, history and geography reflect the social knowledge.

K.17.2. Social sciences are like culture. Because there are characteristics, principles, knowledge and qualities that make societies a society.

K.9.1. Social sciences is like our life story. Because it tells the history of our geography and history.

K.54.3. Social sciences are like postcards. Because the picture he paints about a subject has cultural elements.

K.5.1. Social sciences is like a map. Because it embodies the effects in the geographies where people exist.

K.108.4. Social sciences is like history. Because we can convey our culture through the science of history. 
K.24.2. Social sciences are like geography. Because it covers everything that comes from different lifestyles and cultures.

K51. 2. Social sciences are like Civilization. Because it covers all the products that societies put forth.

K85. 3. Social sciences is like a book. Because it contains a lot of information about humanity and cultures.

K75. 3. Social sciences is like a door. Because it opens the door and shows children new ways by opening fields such as history, geography, sociology.

K.6.1. Social sciences is like an encyclopedia. Because in it, you can find the necessary knowledge of humanity that you're curious about.

\section{Primary Education Category}

When the grounds of the metaphors of the prospective teachers were examined, they produced 7 different metaphors that emphasized the primary educational dimension of the concept of social sciences. Metaphors are in the form of family, hours, preparation for life, emergency, brain, spring, and seed.

Examples of metaphors produced for this category are given below.

K.2.1. Social sciences are like family. Because it affects people's lives from the day they were first taught.

K.22.2. Social sciences are like clockwork. Because it starts in elementary school and works all the time.

K.29.2. Social sciences are like preparing for life. Because it offers information from every aspect of life.

K.60.3. Social sciences are like First Aid. Because it contains information that will be useful to us for the rest of our lives in terms of its subjects."

K.68.3. Social sciences are like brains. Because everything is the basis of every issue.

K.89.4. Social sciences is like spring. Because these subjects keep people alive and prepare them for the future.

K.105.4. Social sciences are like seeds. Because, like watering, it grows as it is learned and learned.

When the metaphors and analogy reasons for the concept of social sciences were examined, it was observed that the students of basic education emphasized that it was a field of study where knowledge and skills related to social life were gained.

\section{Metaphors and Categories for Social Sciences Teaching of Primary Teacher Candidates}

Table 4

Metaphors and frequency distributions developed by Primary School teacher candidates for Social Sciences teaching

\begin{tabular}{llcclc}
\hline Range & Metaphors & $\begin{array}{c}\text { Frequency } \\
(\mathbf{f})\end{array}$ & Range & Metaphors & $\begin{array}{c}\text { Frequency } \\
\text { (f) }\end{array}$ \\
\hline 1. & Lives & 14 & 36. & Environmental & 1 \\
\hline 2. & Value Education & 9 & 37. & $\begin{array}{l}\text { A Cultural } \\
\text { Event }\end{array}$ & 1 \\
\hline 3. & Guide & 5 & 38. & Jewelry & 1 \\
\hline 4 & Life & 4 & 39. & Invention & 1 \\
\hline
\end{tabular}


KOZANER YENIGÜL, Çiğdem (2020)/ Metaphoric Perceptions of Primary School Teacher Candidates on ....

\begin{tabular}{|c|c|c|c|c|c|}
\hline 5. & Water & 3 & 40. & Google & 1 \\
\hline 6. & Tree & 3 & 41. & Search Engine & 1 \\
\hline 7. & Society & 3 & 42. & Forest & 1 \\
\hline 8. & Mother-Father & 2 & 43. & Skeleton & 1 \\
\hline 9. & Flower & 2 & 44. & Book & 1 \\
\hline 10. & Presentation & 2 & 45. & Electric & 1 \\
\hline 11. & Salata & 2 & 46. & Doctor & 1 \\
\hline 12. & Teaching Life & 2 & 47. & Live & 1 \\
\hline 13. & World & 2 & 48. & Musculature & 1 \\
\hline 14. & History Geography & 2 & 49. & Map & 1 \\
\hline 15. & Love & 2 & 50. & Chess & 1 \\
\hline 16. & Recipe & 2 & 51. & Game & 1 \\
\hline 17. & Physic & 1 & 52. & $\begin{array}{l}\text { Explaining the } \\
\text { Problems }\end{array}$ & 1 \\
\hline 18. & Time & 1 & 53. & Sky & 1 \\
\hline 19. & Sapling Irrigation & 1 & 54. & Teacher & 1 \\
\hline 20. & Chain & 1 & 55. & Rolling & 1 \\
\hline 21. & Industry & 1 & 56. & Plant & 1 \\
\hline 22. & Knit & 1 & 57 & $\begin{array}{l}\text { The ingredients } \\
\text { in the bag }\end{array}$ & 1 \\
\hline 23. & Math & 1 & 58 & $\begin{array}{l}\text { Hidden } \\
\text { Program }\end{array}$ & 1 \\
\hline 24. & A fragile Goods & 1 & 59 & Family Photo & 1 \\
\hline 25. & $\begin{array}{l}\text { The architect of the } \\
\text { city }\end{array}$ & 1 & 60 & $\begin{array}{l}\text { The Democratic } \\
\text { Individual } \\
\text { Educating }\end{array}$ & 1 \\
\hline 26. & Knows Everything & 1 & 61 & Drive a Car & 1 \\
\hline 27. & Compass & 1 & 62 & Noval & 1 \\
\hline 28. & Poem & 1 & 63 & Excited & 1 \\
\hline 29. & Philosopy & 1 & 64 & $\begin{array}{l}\text { Development of } \\
\text { the Baby }\end{array}$ & 1 \\
\hline 30. & Leaf & 1 & 65 & Friend & 1 \\
\hline 31. & $\begin{array}{l}\text { Shine a Light on } \\
\text { Future Generations }\end{array}$ & 1 & 66 & Historian & 1 \\
\hline 32. & Family & 1 & 67 & $\begin{array}{l}\text { One half of an } \\
\text { Apple }\end{array}$ & 1 \\
\hline 33. & School & 1 & 68 & Lunch & 1 \\
\hline 34. & Sacred & 1 & 69 & Chameleon & 1 \\
\hline 35. & $\begin{array}{l}\text { Earthquake } \\
\text { resistant building }\end{array}$ & 1 & & & \\
\hline
\end{tabular}

When Table 4 is examined, it is seen that the teacher candidates have developed 69 metaphors. Life repeated metaphors for teaching social sciences $(\mathrm{f}=14)$, value education $(\mathrm{f}=9)$, Guide $(\mathrm{f}=5)$, Life $(\mathrm{f}=5)$, Water $(\mathrm{f}=3)$, Tree $(\mathrm{f}=3)$, Society $(\mathrm{f}=3)$, Mother-Father $(\mathrm{f}=2)$, Flower $(\mathrm{f}=2)$, Presentation $(\mathrm{f}=2)$, Salad $(\mathrm{f}=2)$, Teaching Life $(\mathrm{f}=2)$, World $(\mathrm{f}=2)$, History-Geography $(\mathrm{f}=2)$, Love $(\mathrm{f}=2)$, Recipe $(\mathrm{f}=2)$ is shaped like. Metaphors developed by only 1 participant, " physics, time, watering seedlings, chain, industry, knitting, 
mathematics, fragile goods, the city architect, compass, poetry, philosophy, leaf, to shed light on to future generations, family, school, earthquake-resistant building, environment, cultural event, jewelry, invention, google, search engine, forest, skeleton, books, electricity, doctor, Live, chameleon, musculature, map, chess, game, describe problems, Sky, teacher, rolling pin, saplings, the ingredients inside the bag, hidden curriculum, family photos, democratic individual educating, driving, novel, excitement, baby development, friend, historian, half an Apple, decedent". 69 different metaphors created for social sciences teaching are divided into various categories according to the explanations made by the participants.

\section{Category Distribution of Metaphors for Social Sciences Teaching}

The metaphors developed by the candidates of primary school teachers for teaching social sciences were grouped into 4 categories: "interdisciplinary, knowledge transfer, cultural transfer, meeting social needs".

Table 5

Metaphors and Categories Developed by Primary School Teacher Candidates for Social Sciences Teaching

\begin{tabular}{|c|c|c|c|c|}
\hline Range & Categories & Metaphors & $\begin{array}{l}\text { Metaphor } \\
\text { (f) }\end{array}$ & $\begin{array}{l}\text { Participant } \\
\text { (f) }\end{array}$ \\
\hline 1 & $\begin{array}{l}\text { Meeting Social } \\
\text { Needs }\end{array}$ & $\begin{array}{l}\text { Value teaching (8), Society (3), } \\
\text { quide (5), Life (4), water (3), } \\
\text { Parent (2) Love (2) recipe(2) } \\
\text { Flower (2) Life teaching (2), a } \\
\text { fragile item(1) city architect(1), } \\
\text { Leaf (1), Family (1), School, } \\
\text { earthquake-resistant building (1), } \\
\text { Google (1) Search Engine } \\
\text { (1)Electricity (1) Doctor (1), } \\
\text { Industry (1), Living (1), } \\
\text { Musculature(1), Describe the } \\
\text { problems (1), a rolling pin (1), } \\
\text { The hidden curriculum (1), family } \\
\text { photos (1),Individual Democratic } \\
\text { Educating (1), Baby (1), lunch } \\
\text { (1), watering the seedlings (1) }\end{array}$ & 31 & 55 \\
\hline 2 & $\begin{array}{l}\text { Knowledge } \\
\text { Transfer }\end{array}$ & $\begin{array}{l}\text { Live (12), Presentation (2), Math } \\
\text { (1), Physic(1), Phiosopy (1), } \\
\text { Sacred (1), Jewelry (1), Book (1), } \\
\text { Chameleon (1), Map(1), History- } \\
\text { Geography (1), Chess (1), Game } \\
\text { (1), Sky(1), Teacher (1), Plant (1), } \\
\text { The ingredients Inside the Bag }\end{array}$ & 21 & 33 \\
\hline
\end{tabular}


(1), Excited (1), Drive a Car (1),

Friend (1), One half of an Apple (1)

\begin{tabular}{lllll}
\hline 3 & Interdisciplinary & Tree (3), Live (2), World (2), & 11 & 16 \\
& & & \\
& & & \\
& Kalad (2), Chain (1), knit (1), \\
& Enviromental (1), Forest (1), \\
& Novel (1) & & \\
\hline 4 & Culture Transfer & $\begin{array}{l}\text { History-Geography (1), Time (1), } \\
\text { Shedding Light on Future } \\
\text { Generations (1), A Cultural } \\
\text { Activity(1), Invention (1), Skeleton } \\
\text { (1), Historian (1), Compass (1) }\end{array}$ & & \\
& & 71 & 112 \\
\hline Total & & & \\
\hline
\end{tabular}

\section{Category of Meeting Social Needs}

It is observed that 55 teacher candidates in this category developed 31 different metaphors. It is observed that the teaching of social sciences has a role in meeting social needs and is related to social life seen. According to the type of the used metaphors were respectively "value teaching $(\mathrm{f}=8)$, society $(\mathrm{f}=3)$, guide $(\mathrm{f}=5)$, life $(\mathrm{f}=4)$, water $(\mathrm{f}=3)$, parent $(\mathrm{f}=2)$, love $(\mathrm{f}=2)$, recipe $(\mathrm{f}=2)$, flower $(\mathrm{f}=2)$, life teaching $(\mathrm{f}=2)$, fragile item $(\mathrm{f}=1)$, to be the architect of the city $(\mathrm{f}=1)$, leaf $(\mathrm{f}=1)$, family $(\mathrm{f}=1)$, school $(\mathrm{f}=1)$, earthquakeresistant building $(f=1)$, google $(f=1)$, the search engine $(f=1)$, electricity $(f=1)$, doctor $(\mathrm{f}=1)$, industry $(\mathrm{f}=1)$, living $(\mathrm{f}=1)$, musculature $(\mathrm{f}=1)$, describe the problems $(\mathrm{f}=1)$, a rolling pin $(\mathrm{f}=1)$, the hidden curriculum $(\mathrm{f}=1)$, family photos $(\mathrm{f}=1)$, individual democratic educating $(\mathrm{f}=1)$, baby $(\mathrm{f}=1)$, lunch $(\mathrm{f}=1)$, Watering the seedlings $(\mathrm{f}=1)$ ”.

Examples of metaphors created by teacher candidates are given below.

K.3.1.Teaching social sciences is like watering a sapling. Because the student is a seedling that needs to grow, it grows as it learns its society.

K.27.2.Teaching social sciences is like teaching value. Because it gives the values that hold people together.

K.10.1.Teaching social sciences is like industry. Because it treats the student like it processes the raw material.

K.16.2.Teaching social sciences is like being the architect of the city. Because teaching social sciences makes the student equipped and is essential to society as it is from within life.

K.20.2. Teaching social sciences is like parents. Because it teaches people about life, environment and life.

K.38.2. Teaching social sciences is like water. Because it's necessary to live.

K.100.4.Teaching social sciences is like a flower. Because when you bloom, the flower makes the environment beautiful, and when people learn to live, it becomes beautiful.

K.28.2.Teaching social sciences is like a leaf. Because the tree of social sciences is indispensable in teaching it.

K.61.3.Teaching social sciences is like a guide. Because it guides you through life. 
K.33.2.Teaching social sciences is like family. Because it shows the truth in life.

K.34.2.Teaching social sciences is like school. Because the teaching of social sciences is ready for life.

\section{Knowledge Transfer Category}

A total of 21 metaphors were created by 33 teacher candidates in this category. According to the type of the used metaphors were respectively" ( $f=12)$ live, $(f=2)$ presentation, $(\mathrm{f}=1)$ math, $(\mathrm{f}=1)$ physics, $(\mathrm{f}=1)$ philosophy , $(\mathrm{f}=1)$ sacred, $(\mathrm{f}=1)$ jewelry, $(\mathrm{f}=1)$ book, $(\mathrm{f}=1)$ chameleon, $(\mathrm{f}=1)$ the map, $(\mathrm{f}=1)$ history and geography, $(\mathrm{f}=1)$ chess, $(\mathrm{f}=1)$ the game, $(\mathrm{f}=1)$ sky, $(\mathrm{f}=1)$ teacher, $(\mathrm{f}=1)$ plant, $(\mathrm{f}=1)$, the ingredients inside the bag, $(\mathrm{f}=1)$ excited, $(\mathrm{f}=1)$ drive a car, $(\mathrm{f}=1)$ friend , $(\mathrm{f}=1)$ one half of an apple" is shaped like. When the metaphors of the teacher candidates were examined, they evaluated the extent of knowledge transfer in the context of benefiting from the disciplines of Social Sciences. The most repeated in the category of information transfer is the metaphor of life $(f=12)$. Participants considered the teachers in this category to be the ones who convey knowledge or guide the student in structuring knowledge and expressed views based on the teacher's influence in teaching social sciences. When the metaphors and justifications of some participants were examined, they stated that the students remained passive in teaching social sciences and that a conceptual-based teaching was done. No more than 3 of the metaphors in this category. It is noteworthy that it has been developed by class candidates who are studying in the classroom. Teaching Grade 6. it can be said that the "Social sciences teaching" course given in the semester creates awareness in the candidates of teachers. The metaphor of" life "is codified both in the category of" knowledge transfer "and in the category of" interdisciplinary", while the metaphor of history - geography is codified in the category of knowledge transfer and culture transfer.

Examples of metaphors belonging to this category are as follows:

K1. 1. Teaching social sciences is like physics. Because in physics, you memorize formulas, and in social sciences, you memorize history.

K.5.1.Teaching social sciences is like life. Because we learn from life.

K.43.2.Teaching social sciences is like presentation. Because you have to prepare before class.

K.46.2.Teaching social sciences is like a jewel. Because valuable knowledge teaches.

K.57.3. Teaching social sciences is like a book. Because he expects a different adventure in every subject to be taught.

K.66. 3.Teaching social sciences is like Chameleon. Because it changes the pattern for each learning, it offers different alternatives.

K.69.3.Teaching social sciences is like a map. Because only certain shapes appear when taught superficially from the outside. But when it's taught the way it should be, the student will see the real thing.

K.70.3.Teaching social sciences is like chess. Because it is necessary to consider every different situation in the teaching of this course.

K.71.3. Teaching social sciences is like a game. Because it can raise awareness by playing and playing games.

K.74.3.Teaching social sciences is like the sky. Because it can be shown as snow, rain, rainbows with all its beauties; it can also be shown in adverse conditions such as storms, 
swells, hail.

K.76.3.Social sciences teaching is like a teacher. Because he should think about how to share his knowledge.

K.79.3. Teaching social sciences is like sapling. Because it grows and develops as it feeds.

\section{Interdisciplinary Category}

A total of 11 metaphors were created by 16 teacher candidates in this category. According to the frequency of usage, metaphors were respectively " $(f=3)$ tree, $(f=2)$, live $(\mathrm{f}=2)$ world , $(\mathrm{f}=2)$ salad , $(\mathrm{f}=1)$ chain , $(\mathrm{f}=1)$ knit, $(\mathrm{f}=1)$ knows everything, $(\mathrm{f}=1)$ poetry, $(f=1)$ enviromental, $(f=1)$ forest, $(f=1)$ novel" form. When the metaphors produced by the teacher candidates are examined, it is seen that they consider social information in an interdisciplinary dimension.

Examples of metaphors belonging to this category are given below:

K.39.2.Teaching social sciences is like life. Because he teaches a lot of different things in life. K.11.1.Teaching social sciences is like knitting, putting the contents together and bringing out a new product.

K.53.2.Teaching social sciences is like a forest. Because it holds together different but similar formations.

K.81.3.Teaching social sciences is like a tree. Because the focus of this course is human, its branches cover many subject areas.

K.42.2.Teaching social sciences is like making salads. Because it is necessary to use many materials in the teaching of this course.

K.93.4. Teaching social sciences is like a novel. Because you need to relate to a lot of issues.

\section{Culture Transfer Category}

In this category 8 different metaphors have been produced by 8 teacher candidates. These metaphors are" history-geography, time, shedding light on future generations, a cultural event, invention, skeleton, historian, compass". When the metaphors developed by the prospective teachers were examined, it was observed that they indicated justifications for the role social information acquired in cultural transfer due to its nature.

Examples of metaphors belonging to this category are given below:

K.30.2.Teaching social sciences is like shining a light on future generations. Because students learn the characteristics, culture, morality and honesty of their society from social sciences.

K.49.2.Teaching social sciences is like exploration. Because connecting the past with the future requires discovery.

K.54.3.Teaching social sciences is like a skeleton. Because, thanks to this teaching, we keep cultures alive.

K.45.2.Teaching social sciences is like a cultural activity. Because it explains the culture of the society in which it lives and presents the effects of other cultures. They expressed their opinion.

\section{Result and Conclusion}

In this study, which aims to reveal the social sciences concept and metaphorical perceptions of the classroom teacher candidates, it is observed that 112 participants 
produced 61 different metaphors related to the social sciences concept and 69 different metaphors related to social sciences teaching. In line with the aim of the study, categories were created by examining the reasons of the metaphors created by the participants and by examining the research conducted in the literature (Akça Berk, Gültekin \& Çençen, 2015; Beldağ \& Geçit, 2016; Gömleksiz, Kan \& Öner, 2012). Concepts of social sciences "social - vital, interdisciplinary, cultural resources and basic education, including "while collecting 4 different categories of research that constitute another dimension in a similar way for the teaching of social sciences "to satisfy social needs, information transfer, interdisciplinary, and cultural transfer" as discussed in 4 different categories. When the categories for the concept of social sciences were evaluated in terms of their frequency, it was determined that the information was listed as social-vital ( $\mathrm{f}=64)$, interdisciplinary $(\mathrm{f}=28)$, cultural resource $(\mathrm{f}=13)$ and primary school $(\mathrm{f}=7)$. The category of" social-vital " is the category most developed in metaphors. The most frequently repeated metaphor of life is noted in this category. For the concept of social sciences, the social-vital category is the category in which the most metaphors are produced. The most frequently repeated metaphor of life is noted in this category. Akça Berk et al. (2015) his research similarly obtained the vital-social category. The category "social sciences as life itself" is the category with the highest frequency, according to the results obtained in the study (Beldag \& Geçit (2016).

The category of meeting social needs created by examining the grounds of metaphors for social sciences teaching is also the category in which most metaphors are developed. In this category, the candidates of the classroom teachers have presented reasons that emphasize the role of social sciences teaching in meeting social needs. It is the metaphor of teaching values that is most often repeated in this category. Values play an important role in establishing and maintaining an orderly social structure (Kan, 2010). Therefore, it can be said that the class teacher candidates are aware of the importance of teaching social sciences in the acquisition of social values. These results reveal that social sciences is associated with social life. Social sciences is a course on social life itself (Karakuş, 2006). Social sciences is a course designed to educate effective, productive, Democratic and ageappropriate citizens by taking advantage of the knowledge required by the social dimension, which is an important part of human life (Doğanay, 2005). Social-vital in the category of "life, daily life, life, live, life itself, the environmental, socialization, to breathe, nature" covering the social needs for teaching social sciences in the category of, "teaching values, community, Guide, life, teaching earthquake-resistant building, Nov my site, an individual democratic educating" discussed the importance of social information such as social metaphors to produce shows.

They developed 19 metaphors in the interdisciplinary category of social sciences and 23 metaphors in the interdisciplinary category of social sciences teaching. When the grounds of the metaphors produced by the candidates of teachers are examined, it is stated that social sciences consists of many human disciplines and fields of study. As Kaya \& Öner (2017) notes, social sciences, a collective teaching course, uses the knowledge, 
skills and values produced by the social sciences disciplines it is nurturing. Social sciences is a literature created in an interdisciplinary context. Hence elementary school 4. the development of metaphors in the "interdisciplinary" category of the class teacher candidates who will be responsible for this course reflects their perspective on the concept of social sciences. Koçoğlu (2014) social sciences teachers ' perception of the concept of social sciences through the metaphors developed by the participants, social sciences concept is based on different social disciplines in terms of considering the image of integrity as the category of social sciences. Although the context of the study is different, the results are similar. The candidates of the classroom teachers developed 11 different metaphors in the Cultural Resource category for the concept of social sciences and 9 different metaphors in the cultural transfer category for social sciences teaching. Social sciences course is one of the courses that introduces the characteristics, traditions and customs of society and its culture (Aslan \& Gökkaya). When the explanations related to metaphors are evaluated, it is seen that the candidates of teachers take social knowledge in the context of the elements that constitute social values and culture. When social sciences programs are taken into consideration in the cultural dimension, it is observed that while the basic citizenship education program aims to acquire Turkish culture in many dimensions, it also includes gains to recognize different cultures. These achievements are covered within the cultural and heritage learning area and global connections learning area (İbrahimoğlu, 2018). It is thought that the students of the first and second grade students interpret the concept of social sciences through metaphors through their past lives. Because "social sciences teaching" is included in the third year of the undergraduate program. The candidates of the classroom teachers who take this course have knowledge about social sciences teaching and their specific goals.

Seven different metaphors have been developed in the "primary education" category, which was created for the teaching of social sciences. When the metaphors related to the concept of social sciences are examined, it is stated that basic education students are given basic skills related to social life and that it is a literature.

It is observed that the candidates of the primary teachers emphasize the importance of the role of the teachers who teach the course in the knowledge transfer category created for the teaching of social sciences. There have been statements that the teaching of social sciences is memorialized. At the same time, the student who makes suggestions for active learning in the teaching of the course (K.71.3., K.69.3, K.70.3) participants are also available.

Students who develop metaphors in the knowledge transfer category are taught in the third grade and therefore their metaphors for teaching the course are different from those of the first and second grade teachers. 
The knowledge, skills and values gained in primary school form the basis for the following levels of Education. Social sciences is one of the primary education courses aimed at raising active citizens in primary education. In this context, primary school 4. grade teachers who are responsible for teaching social sciences courses in the classroom should have sufficient knowledge about the field and teaching of social sciences. At this point, a great task falls on the education faculties that train teachers. The attainment from past lives of the teacher candidates also affect their perception of a literature. Research that reveals the perspectives and perceptions of teacher candidates in education faculties is important in this respect. The fact that numerous studies have been done to determine perceptions of concepts through metaphors suggests that metaphors are a powerful research tool in determining perceptions (Kaya, 2014). When the literature is examined, there is no study that reveals the metaphorical perceptions of classroom teachers and classroom teacher candidates towards the concept/teaching of social sciences.

The findings of the study reveal the perception that social information is an area of life that mixes social needs. In this context, in order to ensure effective social sciences teaching in primary education, revealed through the metaphors of prospective teachers' perception of social information for similar studies in different regions, to be done with more participants might offer different perspectives

\section{References}

Akça Berk, N., Gültekin, F. \& Çençen, N. (2015). The metaphors of social studies candidate about social studies course and social studies teachers". Ahi Evran Üniversitesi Kırşehir Eğitim Fakültesi Dergisi, 16(1), 183-199.

Alpaslan, S. \& Kutanis, R. Ö. (2007). The role of metaphors on producing scientific knowledge: supporter or barrier? Bilgi Sosyal Bilimler Dergisi,15(2), 1-17.

Aslan, C. A. \& Gökkaya, A. K. (2004). Programme the politics of the education system Ec applies to the general aims of social science lesson. Gazi Ë̆itim Fakültesi Dergisi, 24(3), 227-244.

Beldağ, A., \& Geçit, Y. (2016). The analysis of social studies teachers' perceptions towards "social studies" concept with the help of metaphors. Abant İzet Baysal Üniversitesi Eğitim Fakültesi Dergisi, 16, 1173-1189.

Beldăg, A. \& Geçit, Y. (2017). Social studies teachers' perceptions regarding the concept "geography": a phenomenological study. Eastern Geographical Review, 22(37), 99-112.

Büyüköztürk, Ş., Kılıç Çakmak, E., Karadeniz, Ş. \& Demirel, F. (2008). Bilimsel araştıma yöntemleri. Ankara: Pegem A Yayıncilık.

Çelikkaya, T. \& Yakar, H. (2015). Perceptions of social studies preservice teachers related to the concept of social studies: metaphor analysis sample. International Online Journal of Educational Sciences, 7(4), 188-207.

Çelikten, M. (2006). Culture and teacher metaphors used in educational system. Sosyal Bilimler Enstitüsü Dergisi, 2, 269-283.

Değirmenci, Y. (2019). An examination of metaphors regarding the concept of "natural disaster" developed by prospective classroom teachers. International Journal of Geography and Geography Education, 39, 83-94 
Değirmenci, Y \& Eskici, B. (2019). Examination of prospective teachers' perceptions of active citizenship. OPUS- International Journal of Society Researches, 11(18), 232-256.

Doğanay, A. (2005). Sosyal bilgiler öğretimi, C. Öztürk \& D. Dilek (Eds.), Hayat bilgisi ve sosyal bilgiler ögretimi (pp. 17-52). Ankara: Pegem A Yayıncılık.

Dunn, A. W. (1916). The Social studies in secondary education: A six-year program adapted both to the 6-3-3 and the 8-4 plans of organization. Washington: Goverment Print Office.

Durmuş, E. \& Baş, K. (2016). The metaphoric perception of social sciences teacher candidates' about the concept of geography. Firat University Journal of Social Science, 26(1), 75-92.

Geçit, Y. \& Gençer, G. (2011). Determining the geographical perception of the 1st. grade students in the department of primary education through metaphor (Example of Rize University) Marmara Coğrafya Dergisi, 23, 1-19.

Gömleksiz, M.N., Kan, A. Ü. \& Öner, Ü. (2012). Metaphorical perceptions of elementary school students toward social studies course. Erzincan University Journal of Education Faculty, 14(2), 419-436.

Gürdoğan Bayır, Ö. (2016). The role of social studies course in creating society with skilled citizens: Pre-service elemantary teachers express their views. Turkish Online Journal of Qualitative Inquiry, 7(4), 493-520.

İbrahimoğlu, Z. (2018). Social studies teacher candidates' approach to culture and different cultures. Uludağ Üniversitesi Eğitim Fakültesi Dergisi, 31(1), 119-152.

Jensen, D. F. N. (2006). Metephors as a bridge to understanding educational and social contexts. Interternational Journal of Qualitative Methods, 5(1), 36-54.

Johnson, M. (1987). The body in the mind: The bodily basis of meaning, imagination, and reason. Chicago: University of Chicago Press.

Kan, Ç. (2010). Sosyal bilgiler dersi ve değerler eğitimi. Milli Ĕgitim Dergisi, 187, 138-145.

Karakuş, F. (2006). The effect of constructivist learning and authentic assessment approach on social studies teaching students' academic achievement retention and attitudes towards social studies (Doctoral Thesis) Çukurova Üniversitesi, Adana.

Kaya, M. F. (2014). Social studies teachers' perceptions related to environmental problems: a sample analysis of metaphors. Turkish Studies, 9(2), 917-931.

Kaya, E.\& Öner, G. (2017). 100. yaşındaki sosyal bilgiler dersini sosyalleşme ve toplu öğretim ekseninde yeniden düşünmek. Anadolu Üniversitesi Ĕ̈itim Fakültesi Dergisi, 2(1), 1-25.

Koçoğlu, E. (2014). Social studies teachers' perceptions of social studies concepts regarding imaginary. Ahi Evran Üniversitesi Kırşehir Eğitim Fakültesi Dergisi, 15(3), 107-126.

Lakoff, G. \& Johnsen, M. (2003) Metaphors we live by. London: The University of Chicago Press.

Ma, L. \& Liu, A. (2008). A universal approach to metaphors. Intercultural Communication Studies, XVII:1, 260-268.

McCandless, B. (2012). The use and misuse of metaphor in education and education reform. Education, 132(3), 538-357.

Massengill, D., Mahlios, M., \& Barry, A. (2005). Metaphors and sense of teaching: How these constructs influence novice teachers. Teaching Education, 16(3), 213-229. 
Milli Eğitim Bakanlığı (2018). Sosyal Bilgiler Dersi Öğretim Programı. (İlkokul ve Ortaokul 4, 5 , 6 ve 7. siniflar). Retrieved from http://mufredat.meb.gov.tr/Dosyalar/ 201812103847686SOSYAL\%20BILGILLR\%20ÖĞRETIM\%20PROGRAMI\%20.pdf.

Miles, M. B. \& Huberman, M. A. (1994). An expanded sourcebook qualitative data analysis. London: Sage.

Murphy, G. L. (1996). On metaphoric representation. Cognition, 60, 173-204.

National Council for the Social Studies (NCSS) (2016). A Vision of powerful teaching and learning in the social studies: A Position Statement of the National Council for the Social Studies. Social Education, 80 (3), pp 180-182.

Neuman, A. \& Guterman, O. (2017). Metaphors and education: comparison of metaphors for education among parents of children in school and home education. Pedagogy, Culture \& Society, 26(3), 435-447.

Parın, K. (2017). Metaforlar: Hayat, Anlam ve Dil. Söylem Filoloji Dergisi, 2(3), 149-151.

Passe, J., Good, A. \& Libresco, A. S. (2014). Social studies in the age of accountability. In A. S. Libresco, J. Alleman, S. L Field \& J. Passe (Eds.), Exemply elementary social studies:Case studies in practice (pp.1-11). Charlotte, NC: Information Age Publishing, Incorporated.

Saban, A. (2004). Entry level prospective classrom teachers' metaphors about the concept of "teacher". The Journal of Turkish Educational Sciences, 2(2), 131-155.

Saban, A. (2009). Prospective teachers' mental images about the concept of student. The Journal of Turkish Educational Sciences, 7 (2), 281-326.

Tay, B. (2015). Sosyal bilgiler öğretiminin dünü bugünü ve yarını. In R. Turan \& K. Ulusoy (Eds.) Sosyal bilgilerin temelleri. (pp. 2-18). Ankara: Pegem Akademi.

Yob, I. M. (2003). Thinking constructively with metaphors. Studies in Philosophy and Education, 22, 127-138.

Biographical Statement

Çiğdem KOZANER YENİGÜL is an assistant professor at Lefke European University. Her research concerns social sciences education, teaching of geography subjects, and creative drama studies. 